2011-09-15

\title{
Country at a Crossroads: An Insight into How an Economic Crisis Led to Dramatic Policy Change
}

John Hogan

Technological University Dublin, john.hogan@tudublin.ie

Ana Maza

Technological University Dublin

Follow this and additional works at: https://arrow.tudublin.ie/buschmarart

Part of the Social and Behavioral Sciences Commons

\section{Recommended Citation}

Hogan, J., Hara, A. Country at a crossroads: an insight into how an economic crisis led to dramatic policy change. Risks, Hazards, \& Crisis in Public Policy, Vol. 2, Issue 3, Pgs 1-23, October 2011. DOI: 10.2202/

1944-4079.1082

This Article is brought to you for free and open access by the School of Marketing at ARROW@TU Dublin. It has been accepted for inclusion in Articles by an authorized administrator of ARROW@TU Dublin. For more information, please contact arrow.admin@tudublin.ie, aisling.coyne@tudublin.ie,gerard.connolly@tudublin.ie.

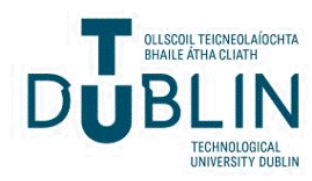


Risk, Hazards \& Crisis in Public Policy

www.psocommons.org/rhcpp/

Manuscript 1082

\section{Country at a Crossroads: An Insight into How an Economic Crisis Led to Dramatic Policy Change}

John W. Hogan, Dublin Institute of Technology Ana Hara, Dublin Institute of Technology 


\title{
Country at a Crossroads: An Insight into How an Economic Crisis Led to Dramatic Policy Change
}

\author{
John W. Hogan, Dublin Institute of Technology \\ Ana Hara, Dublin Institute of Technology
}

\begin{abstract}
In this paper, we try to understand the nature of the changes to Mexican macroeconomic policy in the early 1980s using a critical juncture framework. The framework argues that three elements - crisis, ideational change, and radical policy change - must be identified in order for us to be able to declare, with some certainty, whether an event constitutes a critical juncture. Utilizing this framework, we will ascertain if the changes to Mexican macroeconomic policy constituted a clean break with the past, or were a continuation of previously established policy pathways.
\end{abstract}

KEYWORDS: Mexico, economic, crisis, critical, juncture, ideas 


\section{Introduction}

It is against the background of our current global economic crisis that we examine how Mexico responded to its own economic difficulties in the early 1980s. By the late 1970s, on the surface at least, the future looked bright for Mexico. Its economy was growing, it had discovered oil and its government was spending large sums on state projects and enterprises. However, within a few short years circumstances changed dramatically, leading to a deep questioning of extant macroeconomic policy. Did policy change? What form did this change assume? And what lessons might policy makers today take from this episode?

Sudden policy changes are often blamed on crises of a variety of kinds. We will see the current global economic crisis held up as responsible for the various policy changes that come in its wake. Such crises are regarded as affording politicians the chance to implement new strategies in direct response. This has resulted in an inclination amongst commentators to readily connect economic crises with radical policy changes and deem them to constitute cause and effect. However, here we contend that such linkage is an oversimplification of a far more complex process. It fails to take account of the political circumstances within individual jurisdictions or the idea that economic crises are a necessary, but insufficient, condition for radical policy changes - often such crises are followed simply by policy continuity.

In exploring this issue, we employ the critical juncture framework developed by Hogan and Doyle (2007). According to the framework, a critical juncture consists of three discreet, but interconnected, elements: crisis, ideational change (extant ideational collapse and new ideational consolidation), and radical policy change (see Figure 1).

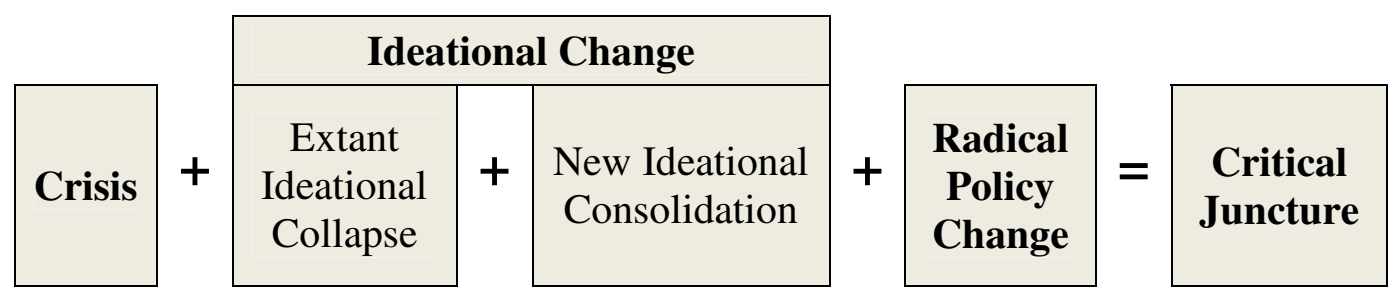

Figure 1. Critical Juncture Framework

The framework's underlying hypothesis is that a crisis can create the environment where change agents can contest extant ideas and the policies based upon them. Replacement of an extant ideational paradigm through the consolidation of a new set of ideas - as a consequence of a crisis - results in a radical policy change. According to this framework, the differentiating factor between crises that result in critical junctures in policies, and those that do not, is 
ideational change. In the absence of ideational change, policy change in response to a crisis will either be first or second order policy change, but not third order (paradigmatic) change. ${ }^{1}$ Policy instrument settings, and the instruments themselves, may change, but without ideational change the hierarchy of goals underpinning a policy will remain unaltered. Ideational change constitutes the variable connecting a crisis and the nature of the subsequent policy change.

Here we will examine whether the economic difficulties affecting Mexico at the start of the 1980s constituted a crisis; whether there was a subsequent change in the ideas underlying extant macroeconomic policy; and what exactly was the nature of the change, if any, to Mexican macroeconomic policy? Employing the framework provides us with a glimpse into the black box of policy making and the mechanics of policy change. The framework's robustness means it can be applied broadly and in so doing renders the concept of the critical juncture less nebulous and case specific.

\section{A Brief Overview of the Critical Junctures Literature}

According to Hogan and Doyle's (2007) theory, a critical juncture consists of a crisis, ideational change and a radical policy change. "Because the decision to select any particular event as the starting point of analysis may seem arbitrary, the investigator is prone to keep reaching back in their search for the foundational causes" (Mahoney 2000, 527). The crucial object is one that sets development along a particular path, the trigger event (Pierson 2004). Periods of policy genesis correspond to critical junctures (Abbott 1997). Mahoney (2001) regards critical junctures as responsible for the implementation of a specific policy arrangement from among a range of choices. The policy pathway then established works to funnel subsequent policies in a particular direction (Pierson and Skocpol 2002).

Comparative and single case studies of various types of change have employed the concept of critical junctures. For some authors, critical junctures are marked by period of swift change, while for others they take place over a much longer period. On the issue of swift change, Garrett and Lange (1995) showed how elections could result in critical junctures by producing overwhelming mandates for policy change. The concept was used to examine transitions from authoritarian regimes by Casper and Taylor (1996), while Hogan and Doyle's (2007) remoulded framework was used to examine changes in macroeconomic policy in Sweden and the US in a comparative historical context. Critical junctures have also been used to examine the differences between Danish politicians' and citizens' attitudes towards the European Union (EU) (Flockhart

\footnotetext{
${ }^{1}$ Here the model borrows from Hall's (1993) concept of first, second and third order change.
} 
Hogan and Hara: Country at a Crossroads

2005). In relation to long term change, Collier and Collier (1991) and Mahoney (2001), in their analyses of regime change and trade union movement development in Latin and Central America, used critical juncture frameworks. For these authors, critical junctures took place over many decades. Akin to path dependence, the critical junctures approach highlights the importance of the past in explaining the present.

\section{Operationalizing the Critical Junctures Framework}

In this paper, we examine changes in Mexican macroeconomic policy in the early 1980s in three stages, employing a variation upon Hogan and Doyle's (2007) critical juncture framework. Three discrete sets of observable implications are developed to test for economic crisis, ideational change, and the nature of policy change.

The existence of a crisis means extant policies cannot be maintained without a general worsening of the current situation (Boin et al. 2005). A crisis could be a war, a revolution, or an economic catastrophe - anything that produces a mandate for policy change. In this case, we will test for an economic crisis, as there is a longstanding debate in the literature on the relationship between economic crises and policy change (Haggard and Kaufman 1995). Such an event raises serious questions about existing policy, and can unleash powerful forces for change in a country that can have a wide-ranging and long lasting impact (Haggard 2003). An economic crisis, therefore, can influence policy preferences (Stevenson 2001).

Ideational change can result in a transformed policy environment, but understanding how ideas influence policy making is something theorists have long grappled with (Pemberton 2000; Taylor 1993). To address the question of why ideas underlying failing policies sometimes change, resulting in policy change, whereas at other times they remain unaltered, we look to Legro's (2000) work on the concepts of extant ideational collapse and new ideational consolidation.

The nature of the subsequent policy change is identified using Hall's (1993) concepts of first, second and third order change. These orders of policy change provide a deeper understanding as to the nuances contained within in the policy change process, as well as the kind of change that is necessary for there to be a critical juncture. 


\section{Identifying a Macroeconomic Crisis}

Identifying a macroeconomic crisis is difficult, as it is a rare and often country specific event. Nevertheless, even events such as these must be made quantifiable, to some extent at least. Kaminsky, Reinhart and Végh (2003) suggest examination of individual variables when studying a currency crisis. However, Pei and Adesnik (2000) and Hogan and Doyle (2007) set out a broad range of qualitative/quantitative criteria for identifying a macroeconomic crisis. General economic indicators, used in conjunction with perceptions of economic performance, can help identify a macroeconomic crisis (Garuba 2006; Kwon 2001). Thus, economic crises have been previously studied using various combinations of subjective and objective criteria. The observable implications employed in this analysis draw upon the criteria developed in the works discussed above.

The economy may have been in crisis if:

01. GDP growth was stagnant or negative,

O2. Debt as a percentage of GNI was above 100 percent,

O3. Inflation was above 15 percent,

04. The interest rate was above 15 percent,

05. Unemployment was above 15 percent,

O6. Opinion polls found the public regarded the economic to be in crisis,

07. The national media regarded the economy to be in crisis,

O8. Economic and political commentators regarded the economy to in crisis,

09. The central bank regarded the economy to be in crisis,

010. Domestic and international organisations monitoring economic performance regarded the economy to be in crisis,

011. Elected representatives regarded the economy to be in crisis, and

012. Government pronouncements on the economy were consistent with a crisis management approach.

\section{Identifying Ideational Change (Collapse and Consolidation)}

An economic crisis can result in the questioning of extant economic policy by society. However, the crisis on its own will not dictate the evolution of economic policy, this being determined by political and ideational processes responding to 
the crisis (Golob 2003). Blyth (2002) contends that ideas facilitate the building of coalitions among agents intent upon resolving a crisis. In this respect, ideas constitute the mechanisms of policy change in a critical juncture (Golob 2003). Hogan and Doyle's (2007) framework argues that for a radical change in policy to take place, it is necessary that actors consolidate around a particular set of new ideas that they have reached consensus upon. The framework locates ideational change at the crossroads of crisis and policy change, determining the type of policy change that occurs in response to the crisis.

If we want to fully understand policy change, it is necessary to take account of the work actors do to produce that change (Zittoun 2009). Hogan and Doyle (2007) argue that three types of change agents are responsible for introducing ideas into the policy making environment: outside influencers, policy entrepreneurs and political entrepreneurs. These change agents can act as either motors for change or hindrances to change (Hogan and Doyle 2007). In this manner, the critical juncture theory formalizes and captures Kleistra and Mayer's (2001) ideas of carriers and barriers to policy change. Thus, the theory accepts Capano's (2009) contention that stability and change are connected at both theoretical and empirical levels.

Outside influencers consist of various print, electronic and online media, and international organisations such as the Organisation for Economic cooperation and Development (OECD) and the International Monetary Fund (IMF). They often advocate new economic paradigms while critiquing the extant ones. Policy entrepreneurs may be academics, economists, commentators, civil servants, pressure groups or others. Crucially, policy entrepreneurs tend to seek access to policy makers in their effort to have their voices heard (Kingdon 1995). The most important group of change agents are what Dahl (1961) calls political entrepreneurs. These are the actors, whether in government or the opposition, with the capacity to utilise the instability of a crisis and the new ideas put forward by outside influencers and policy entrepreneurs in their efforts to bring about policy change (Sheingate 2003). The political entrepreneurs introduce new ideas into the policy making process.

Ideational Collapse. If change agents agree that the extant ideational paradigm is inadequate, and should be replaced, then ideational collapse has occurred. Extant ideational collapse is the first stage in Legro's (2000) two-stage model of ideational change. The observable implications for identifying ideational collapse are:

01. Media critique the current policy paradigm and propose alternative ideas, 
02. International organisations critique the current policy paradigm and propose alternative ideas,

03. There is widespread public dissatisfaction with the current policy paradigm, observable through opinion polls, protests etc.,

04. Academics, economists and civil servants (policy entrepreneurs) critique the current policy paradigm and propose alternative ideas,

O5. Civil society organizations such as the labour unions, employer organizations and consumer groups (policy entrepreneurs) critique the current policy paradigm and propose alternative ideas, and

O6. Opposition political parties (political entrepreneurs) critique the current policy paradigm and propose alternative ideas.

New Ideational Consolidation. Agents must diagnose, and impose on others, their notion of a crisis before collective action to resolve the uncertainty can begin (Blyth 2002). Once extant ideational collapse has occurred change agents will offer solutions. Legro (2000) warns that if they fail to reach consensus on a replacement idea, continuity could result, as society has a tendency to re-embrace the extant paradigm. However, if change agents, led by a political entrepreneur, reach consensus on a replacement idea, it constitutes the second stage of Lergo's (2000) model - consolidation (Sheingate 2003). Observable implications include:

07. Clear alternative ideas developed by policy entrepreneurs,

08. Political entrepreneur combines interests to produce consensus around replacement paradigm, and

09. Political entrepreneur injects new ideas into the policy making arena.

Consensus on the new ideas will protect the policies derived from them. Continuity results from protected ideas, as institutionally embedded ideas ensure that "policy-making becomes possible only in terms of these ideas" (Blyth 2001, 4). In this manner, the critical juncture theory seeks to address Mintrom and Norman's $(2009,650)$ question "by what means can advocates of policy change come to have broad influence?"

\section{Identifying the Degree of Policy Change}

Hogan and Doyle's (2007) theory argues that once change agents, led by a political entrepreneur, consolidate around a new set of policy ideas, radical policy 
change should follow. The theory recognises ideas as capable of altering the policy environment (McNamara 1998). Ideational change is seen as the differentiating factor between crises that result in radical policy change and those that do not.

To discover if a radical change in policy followed ideational change, we use observable implications based upon Hall's (1993) concepts of first, second, and third order policy change. He defines third order changes in policies as radical transformations, with first and second order changes being of lesser magnitude. These observables will enable us to identify, and differentiate, normal and fundamental shifts in macroeconomic policy.

For Hall (1993), extant paradigms can be discredited by their failures and exogenous shocks, leading to a re-examination of extant policy - a paradigmatic shift. These observables also incorporate the ideas of swift and enduring change; it cannot be a long process of incremental adjustment and it should survive at least one change of government - otherwise how can it be a transformative event? Capano and Howlett (2009) point out that clarifying when a policy change can be regarded as fundamental, and the length of time it takes to observe such a change, is usually based on a multi-year perspective to identify actual, as opposed to temporary, policy alterations. Selecting swift change, that survives a government's terms of office, addresses the problems of defining and operationalizing the timing and scope of policy change (Howlett 2009).

The following observable implications indicate that there may have been a radical change in economic policy if:

01. Economic policy instrument settings changed (swiftly and for longer than a government's term of office),

02. The instruments of economic policy changed (swiftly and for longer than a government's term of office), and

03. The hierarchy of goals behind economic policy changed (swiftly and for longer than a government's term of office).

The degree of policy change identified will determine if there has been a critical juncture.

\section{Evaluating the Empirical/Theoretical Fit}

The criteria of strong evidence (SE), medium evidence (ME), weak evidence (WE) and no evidence (NE) will be used here to assess our findings in relation to the observable implications. Coding, using predetermined criteria of this nature, is designed to ensure that our findings can be arranged and analyzed coherently (Maxwell 2005). The more evidence that points towards a crisis, ideational change and third order policy change, the more confidence we can have that a 
critical juncture occurred. This coding allows for a more nuanced understanding of the criteria contributing to a critical juncture. As interpretation of the codes employed is crucial in divining meaning from them, the reporting of findings, in the interest of clarity, usually involves thick description of the categories and their contexts (Geertz 1973; Polgar and Thomas 2008).

\section{Examining Changes in Mexico's Macroeconomic Policy}

Using the critical juncture framework as set out above, we can now examine the changes to Mexico's macroeconomic policy in the early 1980s. In three distinct stages we will test for an economic crisis, ideational change and finally the nature of the policy change that occurred in Mexico. This will enable us determine if the changes to Mexican macroeconomic policy during this time constituted a critical juncture - a sharp break with the past, or were in fact a continuation of previously established policies.

\section{Stage 1: Testing for a Macroeconomic Crisis}

In an effort to increase Mexico's international trade, while decreasing its foreign dependence, the country adopted an import substitution policy after the Second World War (Narula 2002). The development of domestic industries took place behind trade barriers (González 2002; Solis 1971). However, as the internal market was closed off to foreign competition, competitiveness was not crucial for Mexican industries (Hernandez 2010). Despite this, the model appeared successful, as there was a strong demand for Mexican raw materials as the global economy recovered from the ravages of war. Ultimately though, Mexico's policies created a private sector with a mercantile mentality - dependent upon state protection (Hernandez 2010).

During the early 1970s a combination of the first oil crisis and economic mismanagement by the administration of President Luis Echeverria (1970-1976) resulted in a recession (Narula 2002). Increased state spending, in an effort to revive the economy, contributed to inflation and resulted in a rapidly rising national debt that more than tripled between 1970 and 1976 (Lustig 1992). The government's monetary and fiscal indiscipline marked the end of the policy approach known as "stabilising development." The reality was that Mexico's import substitution economy could not compete with global manufacturers such as the United States (US), Japan and West Germany. At the same time, there was growing discontent amongst the middle classes at their inability to influence policy making in the country's single party (Institutional Revolutionary Party (PRI)) dominated culture (Rubio 2009). 
President José López Portillo (1976-1982) came to power facing significant economic challenges (Alarcon and McKinley 1992). He was not long in office when the state owned oil giant Petróleos Mexicanos (PEMEX) discovered vast reserves under the country's northern states (Calderón-Madrid 1997). Thereafter, the expectation was that future oil revenues would resolve the problems in the economy. However, this development permitted extant economic policies to endure, despite increasing evidence of their failures. In the end, the oil boom proved temporary, serving only to delay the day of reckoning when the structural problems in the economy would have to be addressed (Nelson 1990). This is an example the quick fixes often sought by the Mexican political elite, and by presidents who, permitted only one term of office, did not have to worry about the prospect of facing angry voters in a re-election campaign (Tournaud 2008).

As Mexico's development strategy came to depend upon oil revenues, demands increased for more public spending. The government's response was to increase the number of state owned enterprises by 400 percent (Calderón-Madrid 1997; Clavijo and Valdivieso 2000). As a consequence, state expenditures came to outpaced petroleum revenues and government's tax income (Solís 1981). The rate of inflation rose sharply in the early 1980s as a result of this spending (see Table 1). At the same time, the value of the peso rose, reducing the competiveness of exports, apart from oil (McCaughan 1993). This was to have detrimental consequences for the trade balance (Nash 1991).

By the early 1980s, oil prices fell in response to the diminished demand following the oil crises of the 1970s, a weakening global economy and a resultant supply glut (Hershey Jr. 1981). The Mexican economy, with its enduring structural problems, proved incapable of weathering the challenges presented by this combination of circumstances. In 1981, PEMEX and the Secretaría de Programación y Presupuesto (SPP) reported that oil production would not be sufficient to revive the economy. Foreign borrowing became necessary to sustain economic expansion. By 1981 Mexico had borrowed $\$ 78$ billion to fill the chasm between revenues and expenditures (Alarcon and McKinley 1992). However, as interest rates increased in the recessionary US, the money supply to Mexico diminished, while demand for Mexican goods also declined. The higher US interest rates also placed increased pressure on Mexico's debt servicing, as US banks had lent the country some $\$ 25$ billion. By 1982, the cost of servicing Mexico's debt surpassed its oil revenues (Cornelius 1985). The combination of economic mismanagement, falling oil prices and higher interest rates obliterated the benefits the economic growth achieved during the 1970s had bestowed (Starr 2006).

Mexicans, having lost confidence in their economy, began converting their pesos to dollars throughout 1982 (Sancton, Lopez and Ungeheuer 1982). In an effort to stem the flow of capital from the economy, Banco de Mexico permitted 
the dollar price of the peso to double (Banco de Mexico 1983). However, the problems in the Mexican economy became clear for all to see on 13 August, 1982, when:

The government fired the shot heard around the world, announcing that it could not meet interest payments coming due within the next few days and initiating negotiations for bridge loans and rescheduling agreements with the US Treasury, the IMF, and the private commercial banks (Nelson 1990, 97).

Table 1. Economic Indicators for Mexico (1972 - 1983)

\begin{tabular}{|c|c|c|c|c|c|c|}
\hline Year & $\begin{array}{c}\text { Unemployment } \\
(\boldsymbol{\%})\end{array}$ & $\begin{array}{c}\text { Inflation } \\
(\%)\end{array}$ & $\begin{array}{c}\text { Interest } \\
(\%)\end{array}$ & $\begin{array}{c}\text { Government } \\
\text { Debt/GNP } \\
\text { Ratio }\end{array}$ & $\begin{array}{c}\text { Growth } \\
\text { Rates in } \\
\text { Real GDP }\end{array}$ & $\begin{array}{c}\text { Gross Capital } \\
\text { Formation (\%) of } \\
\text { GDP }\end{array}$ \\
\hline 1972 & 7 & 5 & N/A & 18.5 & 8.22 & 20.32 \\
\hline 1973 & 7.3 & 12.04 & N.A & 19.31 & 7.86 & 21.39 \\
\hline 1974 & 7.2 & 23.75 & N/A & 19.73 & 5.78 & 23.18 \\
\hline 1975 & 7.2 & 15.15 & 11.9 & 21.17 & 5.74 & 23.69 \\
\hline 1976 & 6.7 & 15.79 & 11.8 & 27.62 & 4.42 & 22.29 \\
\hline 1977 & 8.8 & 29 & 12.9 & 39.18 & 3.38 & 22.84 \\
\hline 1978 & 6.9 & 17.45 & 15.1 & 35.86 & 8.96 & 23.6 \\
\hline 1979 & 5.7 & 18.17 & 16.4 & 32.79 & 9.69 & 25.95 \\
\hline 1980 & 4.2 & 26.36 & 20.7 & 30.53 & 9.22 & 25.73 \\
\hline $\mathbf{1 9 8 1}$ & $\mathbf{4 . 2}$ & $\mathbf{2 7 . 9 3}$ & $\mathbf{2 8 . 6}$ & $\mathbf{3 2 . 5 9}$ & $\mathbf{8 . 7 7}$ & $\mathbf{2 5 . 9 4}$ \\
\hline $\mathbf{1 9 8 2}$ & $\mathbf{6 . 8}$ & $\mathbf{5 8 . 9 2}$ & $\mathbf{4 0 . 4}$ & $\mathbf{5 3 . 3}$ & $\mathbf{- 0 . 6 3}$ & $\mathbf{2 1 . 5 6}$ \\
\hline $\mathbf{1 9 8 3}$ & $\mathbf{6 . 9}$ & $\mathbf{1 0 1 . 7}$ & $\mathbf{5 6 . 7}$ & $\mathbf{6 6 . 5 3}$ & $\mathbf{- 4 . 2}$ & $\mathbf{1 9 . 7 7}$ \\
\hline
\end{tabular}

Sources: Data Gob (2011); Fleck and Sorrentino (1994); Mitchell (2007); UNdata (2011)

In 1982, the economic indicators for Mexico pointed towards a crisis (Dornbusch and Edwards 1991). As we can see from Table 1, GDP declined by 0.6 percent in 1982 and a staggering 4.2 percent the following year, while the rate of inflation reached 58.92 percent in 1982 and 101.7 percent in 1983. At the same time, interest rates, which had hovered between 30 and 40 percent up to 1981, jumped above 50 percent in 1982 and reached a phenomenal 66.53 percent in 1983. Unemployment jumped towards 7 percent, while more than half the workforce, 20 million people, were underemployed (Cornelius 1985). The country's budget deficit had reached an unsustainable 16.5 percent of GDP (Russell, Bolte and Lopez 1982, 30). Output was down in all industries; auto production declined by a fifth, minerals by a tenth, and agricultural output was also down by a fifth (Russell, Bolte and Lopez 1982). US banks stopped providing loans to Mexican companies, as they already owed over $\$ 600$ million in interest (Malkin, Greenwald and Earle 1983). 
Mexico appeared to be the country most affected by the global downturn of the early 1980s (The Economist 1985). In 1983, as unemployment and the national debt rose, inflation reached triple digits, and the level of capital formation slackened (Table1). By this point, the country was effectively bankrupt. This was to prove Mexico's worst crisis since the Great Depression (Edwards 1995). El País (1983) placed the blame for the disaster on the policies of President Portillo. As a consequence, confidence in Mexico's economy and political elite evaporated. Some saw the crisis as evidence that Mexico's traditional political system was decaying (Russell, Bolte and Lopez 1982).

Minimum wages could not meet the needs of most Mexican families, as the price of basic foodstuffs rose significantly faster (Lustig 1992). Opinion polls revealed a populace gravely worried about their economic future (Basañez 1985). In a desperate move to reduce both speculation against the peso and foreign investors' panic, President Portillo opted to nationalise the banks (Warnock 1995).

In an effort to revitalise the export sector, the peso was devalued on two occasions in 1982 (Katz 1994). However, the economy could not hold onto a sufficient amount of dollars. To counteract the capital flight, new short term loans were taken out, but, together with the peso's devaluation, ultimately this did nothing to resolve the problem (Jiménez 2006). Banco de Mexico's reserves were wiped out in a matter of weeks. Bailey (1988) concludes that the economic turmoil occurred due to four concurrent trends: oil price fall/excessive government outlays; $\$ 15.3$ billion in short-term loans which funded capital flight; the overvalued peso; and the high level of dollarization in the economy.

Under Portillo, GDP grew at 8 percent annually from 1978 to 1981, one of the highest levels in the world. However, by the end of 1982 Mexico had run up a huge national debt, and drastically devalued its currency. President Portillo's Sixth Annual Presidential Report sums up the situation by remarking that the economy was experiencing the worst crisis in its history. ${ }^{2}$ We can see from Table 2 that, with findings indicating strong evidence for 10 of the 12 observables, there is strong evidence that the Mexican economy was in crisis during the early 1980s.

\footnotetext{
${ }^{2}$ Sixth Annual Presidential Report of President López Portillo, September $1^{\text {st }}, 1982$.
} 
Table 2. The Identification of Macroeconomic Crisis

\begin{tabular}{|l|c|}
\hline The Observable Implications & Mexico \\
\hline O1. GDP growth stagnant & SE \\
\hline O2. Debt as a percentage of GNI was above 100\% & NE \\
\hline O3. Inflation above 15\% & SE \\
\hline O4. Interest rate above 15\% & SE \\
\hline O5. Unemployment above 15\% & NE \\
\hline O6. Opinion polls found the public regarded the economic in crisis & SE \\
\hline O7. Media regarded the economy in crisis & SE \\
\hline O8. Economic/political commentators regard the economy in crisis & SE \\
\hline O9. The central bank regard the economy in crisis & SE \\
\hline O10. Domestic/ international organisations regard the economy in crisis & SE \\
\hline O11. Elected representatives regard the economy in crisis & SE \\
\hline O12. Gov pronouncements consistent with a crisis management approach & SE \\
\hline Economic Crisis & SE \\
\hline
\end{tabular}

The general perception amongst politicians, economic commentators, the media and the public at large was one of crisis. The economy was stagnant, inflation and interest rates were very high, the national debt, while not over 100 percent of GNI, was rising rapidly and unemployment, while officially below 10 percent, masked the far higher level of underemployment in the country. Holding with Hogan and Doyle's (2007) critical juncture framework, which argues that a crisis induced consolidation of a new idea - replacing an extant paradigm - will lead to significant policy change, the next section will examine whether ideas underlying Mexican economic policies changed at this time of economic crisis.

\section{Stage 2: Testing for Ideational Change}

PRI presidents traditionally operated populist-redistributive models (Sandersen 1983). When Portillo assumed office in 1976, he was forced to consider expenditure reductions due to the economic downturn following the first oil crisis (Woodhead 1980). However, with the discovery of vast oil reserves, he too was able to adopt a patronage model that sought to incorporate expansive state expenditure with rapid industrialisation (Bailey 1980). Initially, this continuation of the populist approach resulted in high growth rates throughout the late 1970s (see Table 1), but as the economy grew reliant upon oil revenues it became increasingly vulnerable to the vagaries of fluctuating oil prices.

Rather than pay the political price that sweeping redistributive policies-especially tax reform-would have entailed, both the Echeverria administration (1970-1976) and the Portillo 
administration (1976-1982) sought to expand the entire economic pie and increase the role of the state in the economy, as banker, entrepreneur, and employer (Cornelius 1985, 88).

Ironically, despite the country's oil revenue, it became increasingly dependent on foreign borrowing to meet its expenditure commitments (Prest 1982). Once oil prices fell and interest rates rose, Mexico faced the prospect of defaulting on its debts. In response, the Portillo administration, in early 1982, introduced a 12 point plan to stabilise the economy (Taylor and Lopez 1992). The ideas underlying extant economic policy were coming under increasing strain.

The economic crisis dominated the 1982 presidential election. The PRI put forward fiscal conservative Miguel De La Madrid as its candidate (Nelson 1990). While the mechanics of De La Madrid's selection were concealed from the general public, it appears it resulted from shifts in a more conservative direction within the inner circles of the PRI (Sandersen 1983). The choice of De La Madrid constituted a rupture from the party's revolutionary ideology (Cárdenas 2009). With the economy in crisis, and a sense that the PRI and traditional politics were failing to meet the challenges confronting the country, free market advocates demanded a president who would support the rights of private property (Luna, Tirado and Valdes 1987).

Throughout the campaign, which he ultimately won, De La Madrid emphasised the differences between his proposed government and the outgoing Portillo administration. In his inauguration address he declared his opposition to populism and institutional corruption (Cornelius 1985). He stressed that a new moral, political and economic approach was needed. ${ }^{3}$ Locked into the conditionality of a harsh IMF bailout negotiated by the outgoing administration, De La Madrid presented a detailed programme for policy change (Golob 2003).

The range of options open to the government was limited. External financing had dried up in the aftermath of the economic crisis, while oil revenues remained stagnant (Hernandez 2010). Even when oil prices began to recover, PEMEX did not have the capacity take advantage of the situation. It was clear that to maintain economic, political, and social order, a break with the past was required. Acting as a political entrepreneur, De La Madrid championed a new set of ideas on how to manage the economy. Change agents, led by De La Madrid, consolidated around this replacement set of ideas. These involved moving the Mexican economy away from import substitution, towards a more open approach to international trade.

\footnotetext{
${ }^{3}$ First Annual Presidential Report of President Miguel De La Madrid, 1 September, 1983.
} 
We can see from Table 3 that, with strong evidence for the existence of all observable implications, an ideational change followed Mexico's macroeconomic crisis. The ideas underlying extant macroeconomic policy, focused on import substitution industrialisation, had collapsed. Vast public expenditure by a populist president, based on the belief that oil revenues could sustain rapid industrialisation, led the country to the brink of bankruptcy. Research in the 1990s showed that states with abundant resource wealth ironically tend to perform less well economically than their resource hungry counterparts (Karl 1997; Ross 1999).

Table 3. The Identification of Ideational Change

\begin{tabular}{|c|c|}
\hline The Observable Implications & $\begin{array}{c}\text { Mexico } \\
\text { 1981-1983 }\end{array}$ \\
\hline \multicolumn{2}{|l|}{ Ideational Collapse } \\
\hline O1. Media critique the current policy paradigm and propose alternative ideas & SE \\
\hline $\begin{array}{l}\text { O2. International organisations critique the current policy paradigm and propose } \\
\text { alternative ideas }\end{array}$ & SE \\
\hline $\begin{array}{l}\text { O3. There is widespread public dissatisfaction with the current policy paradigm, } \\
\text { observable through opinion polls, protests etc. }\end{array}$ & SE \\
\hline $\begin{array}{l}\text { O4. Academics, economists and civil servants critique the current policy } \\
\text { paradigm and propose alternative ideas }\end{array}$ & SE \\
\hline $\begin{array}{l}\text { O5. Civil society organizations such as the labour unions, employer } \\
\text { organizations and consumer groups critique the current policy paradigm and } \\
\text { propose alternative ideas }\end{array}$ & SE \\
\hline $\begin{array}{l}\text { O6. Opposition political parties critique the current policy paradigm and propose } \\
\text { alternative ideas }\end{array}$ & SE \\
\hline \multicolumn{2}{|l|}{ New Ideational Consolidation } \\
\hline O7. Clear alternative ideas developed by policy entrepreneurs & SE \\
\hline $\begin{array}{l}\text { O8. Political entrepreneur combines interests to produce consensus around } \\
\text { replacement paradigm }\end{array}$ & SE \\
\hline O9. Political entrepreneur injects new ideas into the policy making arena & SE \\
\hline Adoption of New Idea & SE \\
\hline
\end{tabular}

\section{Stage 3: Testing the Nature of Policy Change}

On assuming office, De La Madrid adopted a crisis management approach to the economy, declaring "we are in an emergency" in his inaugural address at the end of 1982 (Russell, Bolte and Lopez 1982, 30). He quickly set out a 10 point program of austerity measures - Programa Inmediato de Reordenacion Economica (Program of Immediate Economic Reorganization) (Lustig1998). Acting as a political entrepreneur, he appointed 11 new ministers from the conservative wing of the PRI (Nelson 1990). Consequently, his cabinet supported his measures to stabilize and open the economy - prioritising the attraction of 
foreign direct investment (FDI) and focusing on high tech industries (Aboites 1983; Lustig 1992). Macroeconomic stabilisation became the government's priority (Cornelius 1985; Pastor and Wise 1997). The first budget he sent to Congress, seeking to reduce the budget deficit by 50 percent, was draconian (Russell, Bolte and Lopez 1982). But, he intended to continue as he had begun and the budgets introduced in 1983 and 1984 represented a sustained austerity drive (Cornelius 1985). Under De La Madrid, economic policy lurched violently to the right. As access to the president was crucial in influencing policy, policy entrepreneurs cultivated teams of loyal followers within various bureaucracies and departments of government (Golob 2003).

The peso was pegged at a more "realistic" exchange rate and plans were introduced to restructure the federal bureaucracy. De La Madrid introduced conventional monetary and fiscal austerity, and more extensive trade liberalisation. For decades free trade had been "the policy option that dare not speak its name" (Golob 2003, 370). The Mexican government also adopted a less confrontational approach to the IMF and as a result was able to reach agreement with the Fund on an adjustment program to revive the economy (Nelson 1990). This agreement was hailed as a major break-through, allowing the country to avoid a debt moratorium (ISG 1982; Looney 1985).

Recognising that the Mexican government and economy could not rely on revenues from oil exports, De La Madrid saw the solution to financing the country's development in the privatisation of public enterprises, 1,155 of which were sold off (Hernandez 2010). There was an effort to combine structural change and macroeconomic stabilisation, with a focus on export orientated industries (Cornelius 1985). Power was also decentralised to the 31 states to foster competition between their governments and economies, and in so doing help encourage the development of private industries and investment. The overall objective was the integration of the Mexican economy into the global economy.

These policies were to have a long lasting impact upon Mexico's economic, and social, development (Cornelius 1985). The change from "stabilising development" to neo-liberalism - marked by the government's embrace of liberalisation, privatisation and deregulation - was radical (Pastor and Wise 1997). Mexico's import substitutions policies had concentrated on developing the internal market, while the new approach focused on international forces as drivers of liberalisation (Middlebrook 2004). However, a major concern was the inability of Mexican industries to compete in foreign markets, and the low level of internal saving available to finance growth. The relaxation of restrictive FDI laws was a clear signal of the government's desire to attract foreign industries to Mexico. In early 1984 new guidelines were issued specifying the conditions under which majority foreign ownership of companies could be permitted (Cornelius 1985). This development allowed Mexican businesses to 
begin forging relationships with foreign firms Tournaud (2008). All of these reforms and cutbacks enabled Mexico reach its IMF targets for reducing the public sector deficit and limiting new public sector external indebtedness. Unfortunately, the recessionary impact of this strategy was very severe and much of the work of economic adjustment was left to De La Madrid's successor (Pastor and Wise 1997).

The result of these neo-liberal reforms was a transformation in the relationship between state and private sector of the economy (Middlebrook 2004). For decades the PRI had kept private sector interests at a distance, but now all that changed (Golob 2003). As the development of the private sector became crucial to the country's economic revival, the growing importance of the private sector gave it more influence over the formulation of economic policy and increased access to the government. Under De La Madrid, all sections of society gained a voice in a general movement of national liberalisation (Cárdenas 2009). The De La Madrid administration recognised that economic revival had to be based upon economic reality.

Mexican economic history can be divided into that which came before, and that which came after, 1982 (Serra-Puche 2008). The crisis saw the development of a new set of economic policies and a new approach to economic management under De La Madrid. In the wake of the crisis, and the change in the ideas underlying economic policy, Mexico experienced a third-order change in macroeconomic policy. State control was replaced by the market, public ownership was replaced by private ownership and protectionism was replaced by competition (Lustig 2001; Pastor and Wise 1997). From 1982 onwards Mexican economic policy started down a different path, culminating in its accession to NAFTA in 1993 (Hernandez 2010). Table 4 shows that there is strong evidence Mexico's macroeconomic policy's instruments settings, the instruments themselves, and hierarchy of goals behind macroeconomic policy all changed after 1982.

Table 4. The Identification of Change in Government Economic Policy

\begin{tabular}{|l|c|}
\hline The Observable Implications & Mexico \\
\hline O1. Economic policy instrument settings changed & SE \\
\hline O2. The instruments of economic policy changed & SE \\
\hline O3. The hierarchy of goals behind economic policy changed & SE \\
\hline Critical Juncture in Macroeconomic Policy & SE \\
\hline
\end{tabular}

According to Hogan and Doyle's (2007) critical juncture framework, this third order policy change, occurring in the wake of an economic crisis and ideational change, constitutes a critical juncture. These findings, by highlighting 
that an economic crisis is a necessary, but insufficient, condition for radical policy change, show the important role ideational change plays in the process of policy change. The strength of the ideas underlying the import substitution policy protected it and ensured its continuity in the years after 1945. However, by the early 1980s, the policy was found to be failing, and the ideas supporting it were undermined and collapsed. Thereafter, change agents, led by a political entrepreneur in the form of President De La Madrid, consolidated around neoliberal ideas on how to manage the economy, resulting in a third-order change in Mexican macroeconomic policy.

\section{Conclusion}

This paper examined the economic difficulties in Mexico in the early 1980s in order to determine if there had been a critical juncture in that country's economic policies. To answer this question we employed Hogan and Doyle's (2007) three stage critical junctures theory with its attendant range of observable implications. Using this policy change tool, we found strong evidence that the economic malaise in Mexico (1981-1983) constituted an economic crisis. With the economic viability of the state being questioned, import substitution and the restrictions imposed upon FDI were perceived as failing policies. There is strong evidence that the ideational foundations underlying extant economic policy collapsed in the midst of the economic crisis. In response, change agents, led by a political entrepreneur in the form of President De La Madrid, consolidated around new set of ideas on how the manage the economy. These new ideas, involving a 180 degree reversal of previous policy thinking - opening the economy to free trade and pursuing FDI - constituted ideational change. The evidence from our findings suggests that the policies adopted in response to the crisis involved altering the setting, instruments, and hierarchy of goals behind Mexican economic policy - a third order policy change. Thus, we identified a crisis, ideational change, and radical change in macroeconomic policy, which according to the framework constitutes a critical juncture.

The early 1980s witnessed a dramatic shift in Mexican macroeconomic policy. These policy changes, instituted by De La Madrid, were to serve as a cornerstone for Mexican economic policy going forward. Mexico was transformed from an inward to an outward looking economy, with a new outlook on the world. This was to ultimately lead Mexico to reappraise its position both locally and globally and in just over a decade see it join the North American Free Trade Agreement (NAFTA). Since the early 1980s, and despite subsequent economic crises, this overarching policy prescription has remained unaltered due 
to the recognition that protectionism did not work for Mexico and does not constitute a viable alternative to a free market and free trade.

The critical juncture theory shows how established policies are protected by the coherence of their underpinning ideas. However, during a crisis, established policies and their underpinning ideas, having been weakened by failure, can be overcome by political-entrepreneur-led change agents consolidating around new ideas. In the critical junctures theory, the presence or absence of ideational change differentiates between a crisis that is followed by a radical policy change and one that is followed by policy changes of a less dramatic nature. This is a theory capable of examining a range of policy change issues and exploring the nature of that change in the wake of a crisis. As such, the observables used here can easily be modified to examine changes in policies as diverse as foreign policy, education policy and equality policy. The critical juncture theory can help us to understand the impact of crises on policy making and policy change.

\section{References}

Abbott, Andrew. 1997. "On the Concept of Turning Point." Comparative Social Research 16: 85-105.

Aboites, J. 1983. "Acumulación, reproducción de la fuerza de trabajo y crisis en México.” Economía Teoría y Práctica Magazine, Universidad Autónoma Metropolitana: 1.

Alarcón, Diana, and Terry McKinley. 1992. "Beyond Import Substitution: The Restructuring Projects of Brazil and Mexico." Latin American Perspectives 19 (2): 72-87.

Bailey, John. J. 1980. "Presidency, Bureaucracy, and Administrative Reforms in Mexico: The Secretariat of Programming and Budget." Inter-American Economic Affairs 34 (2): 27-59.

Banco de México. 1983. Informe Anual 1982: Sexagésima Cuarta Asamblea General Ordinaria de Accionistas. México D.F.

Basañez, Miguel. (1985), "México 1985: Un pronóstico Electoral. La Lucha por La Hegemonía en México. 1968-1980.” Magazine Nexos, Sociedad, Ciencia y Literatura (Julio)

Blyth, Mark. 2001. "The Transformation of the Swedish Model: Economic Ideas, Distributional Conflict and Institutional Change." World Politics 54(1): 1-26.

Blyth, Mark. 2002. Great Transformations: Economic Ideas and Institutional Change in the Twentieth Century. Cambridge: Cambridge University Press. 
Boin, Arjen, Paul 't Hart, Eric Stern, and Bengt Sundelius. 2005. The Politics of Crisis Management: Public Leadership under Pressure. Cambridge: Cambridge University Press.

Calderón-Madrid, Angel. 1997. "Incomplete Adjustment: Fiscal Policy, Private Savings and Current Account Deficits in Mexico Since 1982." In External Finance and Adjustment, Failure and Success in the Developing World, eds. Karel Jansen and Rob Vos. London: Macmillan Press LTD.

Capano, Gilberto. 2009. "Understanding Policy Change as an Epistemological and Theoretical Problem." Journal of Comparative Policy Analysis: Research and Practice 11 (1): 7-31.

Capano, Gilberto and Michael Howlett. 2009. "Introduction: The Determinants of Policy Change: Advancing the Debate." Journal of Comparative Policy Analysis 11 (1): 1-5.

Cárdenas, Cuauhtémoc. 2009. Mexican politician. Key political figure in Mexico's politics in the 1980s and important political representative of Mexico's opposition parties (Partido de la Revolución Democrática [PRD]) (Interviewed July 2009).

Casper, Gretchen and Michelle M. Taylor. 1996. Negotiating Democracy: Transitions from Authoritarian Rule. Pittsburgh, PA: University of Pittsburgh Press.

Clavijo, Fernando and Susana Valdivieso. 2000. "Reformas Estructurales y Política Macroeconómica: El Caso de México 1982- 1999.” Serie Reformas Económicas, Mayo.

Collier, Ruth. B., and Collier, David. 1991. Shaping the Political Arena: Critical Junctures, the Labour Movement, and Regime Dynamics in Latin America. Princeton, NJ: Princeton University Press.

Cornelius, Wayne. A. 1985. "The Political Economy of Mexico under De La Madrid: Austerity, Routinized Crisis, and Nascent Recovery.” Mexican Studies 1 (1): 83-124.

Dahl, Robert. 1961. Who Governs? Democracy and Power in an American City. New Haven, NJ : Yale University Press.

Data Gov. 2011. Governance Indicators Database [WWW document]. URL http://www.iadb.org/DataGob/index.html [last accessed 25 May]

Dornbusch, Rudiger and Sebastian Edwards. 1991. The Macroeconomics of Populism in Latin America. Chicago, Ill: The University of Chicago Press.

Edwards, Sebastian. 1995. Crisis and Reform in Latin America: From Despair to Hope. Washington, DC: Oxford University Press.

El País. 1983. "México en crisis económica." El País, 1 January, 4.

Fleck, Susan and Constance Sorrentino. 1994. "Employment and Unemployment in Mexico's Labour force." Monthly Labour Review, November, 3-18. 
Flockhart, Trine. 2005. "Critical Junctures and Social Identity Theory: Explaining the gap between Danish Mass and Elite Attitudes to Europeanization.” Journal of Common Market Studies 43 (2): 251-271.

Garrett, Geoffrey and Peter Lange. 1995. "Internationalization, Institutions, and Political Change." International Organization 49 (4): 627-655.

Garuba, Dauda S. 2006. "Survival at the Margins: Economic Crisis and Coping Mechanisms in Rural Nigeria." Local Environment 11 (1): 17-36.

Geertz, Clifford. 1973. The Interpretation of Cultures. New York: Basic Books.

Golob, Stephanie. 2003. "Beyond the Policy Frontier: Canada, Mexico, and the Ideological Origins of NAFTA." World Politics 55 (3): 361-398.

González, M. L. 2002. La Industrialización en México, Instituto de Investigaciones Económicas, UNAM, México.

Haggard, Stephen. 2003. Economic Crisis and Corporate Restructuring in Korea: Reforming the Chaebol. Cambridge: Cambridge University Press.

Haggard, Stephen and Robert R. Kaufman. 1995. The Political Economy of Democratic Transitions. Princeton, NJ: Princeton University Press.

Hall, Peter. A. 1993. "Policy Paradigms, Social Learning, and the State: The Case of Economic Policy Making in Britain." Comparative Politics 25 (3): 275-296.

Hernandez, Luis Miguel Beristain, 2010. Director of Professional Development, Enterprise Development and Social Development at ITESM (Interviewed December).

Hershey Jr., Robert D. 1981. "How the oil glut is changing business." The New York Times, 21 June, 1.

Hogan, John and David Doyle. 2007. "The Importance of Ideas: An A Priori Critical Juncture Framework." Canadian Journal of Political Science 40 (4): 883-910.

Howlett, Michael. 2009. "Process Sequencing Policy Dynamics: Beyond Homeostasis and Path Dependency." Journal of Public Policy 29 (3): $241-62$.

IGS. 1982. "Mexican Crisis and Response." Economic and Political Weekly 17 (43): 1720.

Jiménez, Martin. 2006. "Las crisis económicas de México en 1976 y 1982 y su relación con la criminalidad." A Journal for the Humanities and Social Sciences 11 (3): 27-32.

Kaminsky, Graciela L., Carmen M. Reinhart and Carlos A. Végh. 2003. "The Unholy Trinity of Financial Contagion." Journal of Economic Perspectives 17 (4): 51-74.

Karl, Terry. L. 1997. The Paradox of Plenty: Oil Booms and Petro-States. Berkeley, CA: University of California Press. 
Hogan and Hara: Country at a Crossroads

Kingdon, John W. 1995. Agendas, Alternatives, and Public Policy, $2^{\text {nd }}$ ed. New York, NY: Harper.

Kleistra, Yvonne and Igor Mayer. 2001. "Stability and Flux in Foreign Affairs: Modelling Policy and Organizational Change." Cooperation and Conflict 36 (4): 381-414.

Kwon, S. 2001. "Economic Crisis and Social Policy Reform in Korea." International Journal of Social Welfare 10 (2): 97-106.

Legro, J. W. 2000. "The Transformation of Policy Ideas." American Journal of Political Science 44 (3): 419-432.

Looney, Robert. E. 1985. Economic Policymaking in Mexico: Factors Underlying the 1982 Crisis. Durham, NC: Duke University Press.

Luna, Matilde, Ricardo Tirado and Francisco Valdes. 1987. "Businessmen and Politics in Mexico, 1982 -1986." In Government and Private Sector in Contemporary Mexico, eds. Sylvia Maxfield and Ricardo Anzaldua. San Diego: Center for US-Mexican Studies, 13-44.

Lustig, Nora. 1992. Mexico: The Remaking of the Economy. Washington, DC: The Brookings Institute.

Lustig, Nora. 1998. Mexico: The Remaking of the Economy. $2^{\text {nd }}$ ed. Washington, DC: The Brookings Institute.

Lustig, Nora. 2001. "Life is not Easy: Mexico's Quest for Stability and Growth." The Journal of Economic Perspectives 15 (1): 85-106.

Mahoney, James. 2000. "Path Dependence in Historical Sociology." Theory and Society 29 (4): 507-548.

Mahoney, James. 2001. "Path Dependent Explanations of Regime Change: Central America in Comparative Perspective." Studies in Comparative International Development 36 (1): 111-141.

Malkin, Lawrence, John Greenwald and Mary Earle. 1983. "The Cartel is Losing its Clout." Time Magazine, 1 January, p. 27.

Maxwell, Joseph A. 2005. Qualitative Research Design: An Interactive Approach. $2^{\text {nd }}$ ed. London: Sage.

McCaughan, Edward. J. 1993. "Mexico's Long Crisis: Toward New Regimes of Accumulation and Domination." Latin American Perspective 20 (3): 631.

McNamara, Kathleen. R. 1998. The Currency of Ideas: Monetary Politics in the European Union. Ithaca, NY: Cornell University Press.

Middlebrook, Kevin. J. 2004. Dilemmas of Political Change in Mexico. London: Institute of Latin America Studies, University of London.

Mintrom, Michael and Phillipa Norman. 2009. "Policy Entrepreneurship and Policy Change." The Policy Studies Journal 37 (4): 649-67.

Mitchell, Brian R. 2007. International Historical Statistics: The Americas 17502005. $6^{\text {th }}$ ed. Macmillan: Basingstoke. 
Narula, Rajneesh. (2002), "Switching from Import Substitution to the "New Economic Model" in Latin America: A case of not learning from Asia." Strategic Management Society Annual Conference, Paris, France, September 2002. Copenhagen Business School and University of Oslo, Working paper No. 4.

Nash, John. 1991. "Mexico: Adjustment and Stabilisation." In Restructuring Economies in Distress: Policy Reform and the World Bank, ed. Vinod Thomas, Ajay Chhibber, Mansoor Dailami, and Jaime de Melo. Oxford: Oxford University Press, 494-514.

Nelson, Joan. M. 1990. Economic Crisis and Policy Change. Princeton, NJ: Princeton University Press.

Pastor, Manuel and Carol Wise. 1997. "State Policy, Distribution and Neoliberal Reform in Mexico." Journal of Latin American Studies 29 (2): 419-456.

Pei, Minxin and David Adesnik. 2000. "Why Recessions Don't Start Revolution." Foreign Policy 118(1): 138-151.

Pemberton, Hugh. 2000. "Policy Networks and Policy Learning: UK Economic Policy in the 1960s and 1970s." Public Administration 78 (4): 771-792.

Pierson, Paul. 2004. Politics in Time: History, Institutions, and Social Analysis. Princeton, NJ: Princeton University Press.

Pierson, Paul and Theda Skocpol. 2002. "Historical Institutionalism in Contemporary Political Science." In Political Science: The State of the Discipline, eds. Ira Katznelson and Helen V. Milner. New York, NY: W.W. Norton, 693-721.

Polgar, Stephen and Shane A. Thomas. 2008. Introduction to Research in the Health Sciences. $5^{\text {th }}$ ed. Edinburgh: Churchill Livingstone.

Prest, Michael. 1982. "Gold Goes Alone as the Bulls Dig In," The Times, 10 September, 7.

Ross, Michael L. 1999. "The Political Economy of the Resource Curse." World Politics 51 (2): 297-322.

Rubio, Luis. 2009. Mexican writer on politics, and economics. (Interviewed February 2009)

Russell, George. Gisela Bolte and Laura Lopez. 1982. "Mexico we are in an Emergency." Time Magazine, 20 December, 30.

Sancton, Thomas. A., Laura Lopez, and Fredrick Ungeheuer. 1982. "Mexico: Frightening Specter of Bankruptcy." Time Magazine, 30 August, 40.

Sanderson, Steven. E. 1983. "Presidential Succession and Political Reality in Mexico." World Politics 35 (3): 315-334.

Serra-Puche, J. 2008. Mexican Politician. Secretary of Commerce and Industry in 1988; Treasury Secretary in 1994; and Mexico's representative in NAFTA negotiations in early 1990s. (Interviewed May 2008). 
Hogan and Hara: Country at a Crossroads

Sheingate, Adam. D. 2003. "Political Entrepreneurship, Institutional Change, and American Political Development." Studies in American Political Development 17: 185-203.

Solis, Leopoldo. 1971. "Mexican Economy Policy in the Post-War Period: The Views of Mexican Economists." The American Economic Review, Supplement, Surveys of National Economic Policy Issues and Policy Research 61 (3): 2-67.

Solís, Leopoldo. 1981. Economic Policy Reform in Mexico. A Case Study for Developing Countries. Elmsford, NY: Pergamon.

Staar, Pamela. K. 2006. "Mexican Foreign Policy." In Changing Structure of Mexico: Political, Social, and Economic Prospects, $2^{\text {nd }}$ ed., ed. Laura Randall. New York, NY: M.E. Sharpe, 49-57.

Stevenson, Randy. T. 2001. "The Economy and Policy Mood: A Fundamental Dynamic of Democratic Politics?" American Journal of Political Science 45 (3): 620-633.

Taylor, Alexander L. and Laura Lopez. 1982. "Mexico's Petroleum Hangover." Time Magazine, 29 March, 38.

Taylor, John. B. 1993. Macroeconomic Policy in the World Economy. New York, NY: W.W. Norton.

The Economist. 1985. "Time to Put Paid to Aid." The Economist. 6 April, 7.

Tournaud, Nicolas Foucras. 2008. Head of the Political Science department, ITEMS (Instituto Tecnológico y De Estudios Superiores de Monterrey) Campus Monterrey. (Interviewed August 2008).

UNdata 2011. UNdata A World of Information [www document]. URL http://data.un.org/Data.aspx?d=IFS\&f=SeriesCode\%3a60 [last accessed 10 September].

Warnock, John W. 1995. The Other Mexico: The North American Triangle Completed. London: Black Rose Books.

Woodhead, Lawrence. 1980. "Mexico from Bust to Boom: A Political Evaluation of the 1976- 1979 Stabilization Programme." World Development 8(1): 843-864.

Zittoun, Philippe. 2009. "Understanding Policy Change as a Discursive Problem." Journal of Comparative Policy Analysis: Research and Practice 11 (1): 65-82. 